\title{
Is Pterygium Morphology Related to Loss of Corneal Endothelial Cells? A Cross-Sectional Study
}

This article was published in the following Dove Press journal:

Clinical Ophthalmology

\author{
Syed Bilal Hassan Zaidi ${ }^{\prime}$ \\ Wajid Ali Khan ${ }^{2}$ \\ 'Department of Ophthalmology, Mater \\ Misericordiae University Hospital, \\ Dublin, Ireland; ${ }^{2}$ Pakistan Institute of \\ Ophthalmology (PIO), Department of \\ Cornea and Refractive Surgery, Al-Shifa \\ Trust Eye Hospital, Rawalpindi, Pakistan
}

Correspondence: Syed Bilal Hassan Zaidi Department of Ophthalmology, Mater Misericordiae University Hospital, Dublin, Ireland

Tel +353899568074

Email syedbilalhassanzaidi@gmail.com
Purpose: To determine the difference in mean corneal endothelial cell density (CECD) between the healthy and diseased eyes of the patients with unilateral pterygium with different morphology patterns by using a non-contact specular microscope (SP2000: Topcon Corporation, Japan) and to find out any relationship between severity of pterygium and daily sunlight exposure with the CECD loss.

Methods: A descriptive cross-sectional prospective study was carried out at Al-Shifa Trust Eye Hospital (ASTEH), Rawalpindi, Pakistan from 21st January 2019 to 22nd January 2020. Two hundred eyes ( $n=100$ patients) of age range18 -68 years with unilateral pterygium were selected. Necessary demographic data and essential variables like age, smoking status, occupation, and daily direct sunlight exposure were determined. The severity of pterygium (grading) based on its morphology was determined by slit-lamp examination. CECD of each patient was carried out using a non-contact Specular Microscope. The healthy eye (without pterygium) of a patient was considered as control.

Results: The age range in this study was 18-68 years, with a mean age of $43.80 \pm 24.37$ years with a male to female ratio of $1.6: 1$ (62.00\% males vs $38 \%$ females). Out of six occupations, the most common occupation was labour/construction work $(n=31)$ followed by farming $(n=27)$. The study reported a mean corneal endothelial cell density (CECD) of $2411.61 \pm 143.64$ vs $2751.41 \pm 123.674$ cells $/ \mathrm{mm}^{2}$ in diseased and normal eyes, respectively ( $\mathrm{p}$-value $=0.0001)$. CECD was lower in grade 3 pterygium compared to less severe pterygium $\left\{\right.$ grade $3($ Fleshy $)=2261$ cells $/ \mathrm{mm}^{2}$ vs grade $2($ Intermediate $)=2413$ cells $/ \mathrm{mm}^{2}$ vs grade 1 (Atrophic) $=2459$ cells $/ \mathrm{mm}^{2}$ \} although this difference between the groups was not found to be significant $(\mathrm{p}=0.065)$. No significant association between sunlight exposure and CECD loss was observed $(\mathrm{p}=0.065)$.

Conclusion: This study concluded that the mean corneal endothelial cell density in patients with unilateral pterygium using a non-contact specular microscope were $2411.61 \pm 143.64$ cells $/ \mathrm{mm}^{2}$.

Keywords: pterygium, corneal endothelial cell density, specular microscope

\section{Introduction}

Pterygium, derived from the word "pteron", is an invasive wing-shaped growth of bulbar conjunctiva which encroaches upon the cornea. It is a recurring ocular surface lesion that mostly occurs in warmer countries situated along the equatorial line, Asia, and the Mediterranean region. ${ }^{1}$

It occurs due to the modification of limbal stem cells that, by undergoing hyperplasia, grow towards the cornea. Citations in the previous papers identify the most common risk factors to be genetic, which when coupled with ultraviolet rays and various pro-inflammatory cytokines, lead to the conjunctival matrix 
remodelling, the transition of the conjunctival epithelium to mesenchymal cells, BL dissolution, and conversion of inactive fibroblasts into activated ones thereby causing local inflammation and neovascularization. ${ }^{2}$

These phenomena occur due to mediation by growth factors, specific cytokines, and matrix metalloproteinases. ${ }^{3}$ The mechanism by which ultraviolet rays cause pterygium is unclear. Still, certain studies have shown the mutation in the TP53 tumour suppressor gene in the Stratum Basale of limbal stem cells and up-regulation of cytokines and other growth factors, including interleukins (especially IL1, IL6, and IL8) and Tumour Necrosis Factor (TNF- $\alpha){ }^{4}$ Others argue that heparin-binding epidermal growth factor-like factor (HB-EGF) acts as a potent mitogen and is also present in increased amounts due to activation by ultraviolet $\mathrm{B}$ waves. ${ }^{31,32}$ This facilitation of invasion is carried out by specific proteases produced by the head of the pterygium. Some studies have shown that these biochemical and pathological changes introduced by pterygium formation also act as a precursor of changes in the deeper layers of cornea. ${ }^{5}$

It causes chronic dry eye, poor cosmesis, and altered visual acuity as the pterygium encroaches the visual axis and exerts an astigmatic effect. Indications for treatment include reducing visual acuity, cosmetic complaints, ocular motility limitations, recurrent and chronic inflammatory changes, and sometimes poor fitting of contact lenses. Although pterygium diagnosis has been straightforward, it usually remains an unresolved disease with unsatisfactory surgical results and is often associated with multiple recurrences throughout life.

Pterygium treatment has evolved immensely in the last 10 years, including excision with irradiation or using Mitomycin $\mathrm{C}$ or 5-Fluorouracil. The latest techniques involve placing a conjunctival autograft or amniotic membrane transplant at the excised area. The ocular surface dryness is usually treated with topical lubricants, mild topical steroids, and sometimes potent steroids if secondary inflammation causes severe pain and low quality of life. Due to frequent recurrences, the patient tends to be followed up for more extended periods and advised to make lifestyle modifications like ultraviolet protective sunglasses. ${ }^{8}$

Average corneal endothelial cell density (CECD) is around $2500-3000$ cells $/ \mathrm{mm}^{2}$, with an average annual decrement of about $1 \%$, at birth being 5000 cells/square millimeter. ${ }^{8}$ An internal audit at ASTEH conducted on patients with phacoemulsification with foldable intraocular lenses for mature cataract LOCS-3 Score (Lens Opacification scoring system) with ipsilateral pterygium depicted that significant corneal oedema was present at three months postoperatively compared to those patients without pterygium $(\mathrm{P}<0.01)$ which led to the question if pterygium was associated with increased endothelial cell loss.

It has been shown previously that pterygium itself and the increase in the percentage of the involved cornea by a pterygium are associated with significant corneal endothelial cell loss compared to healthy eyes. ${ }^{6,7}$ However, few recent studies conducted in China and the United States analyzed the Corneal endothelial cell density in patients with unilateral pterygium showed no significant difference between the pterygium and healthy eye. ${ }^{34,36}$ Previous studies have documented the relationship between pterygium encroachment onto the cornea and CECD loss, but very few studies have been done to establish a relationship between the pterygium morphology and CECD loss. Further, there has been little work done in Pakistan that directly addresses pterygium's effects on the corneal endothelium. Due to South Asia's large area and poor socio-economic status, ${ }^{33}$ patients do not sort any treatment for pterygium unless it is causing a severe decrease in vision due to Astigmatism or Ocular surface disease. If such patients require cataract surgery, loss of endothelial cells can be two folds. This study will add to existing knowledge regarding the deleterious effects of chronic pterygium on endothelial cell density and create awareness in clinicians to employ treatment strategies to remove pterygium earlier to avoid complications secondary to chronic endothelial cell loss.

\section{Patients and Methods}

A descriptive cross-sectional study at Al-Shifa Trust Eye Hospital (ASTEH), Rawalpindi, Pakistan, from 21st January 2019 to 22nd January 2020 was conducted after getting approval from Ethics Review Committee (ERC) of Al-Shifa Trust Eye Hospital for the study and data collection. The study was carried out according to the Declaration of Helsinki. After getting informed consent, the research team recorded the necessary demographic data for all the patients.

\section{Patient Selection}

Two hundred eyes ( $n=100$ patients) presenting to the Outpatient Department (OPD) at ASTEH fulfilling the inclusion criteria were selected for this study. The healthy eye 
(ie, without pterygium) of the same patient was taken as control. All adults between 18 and 68 years of age presenting with unilateral pterygium were included in the study. The exclusion criteria included eyes with pseudopterygium, recurrent pterygium, corneal degenerative and hereditary conditions, previous ocular surgery, history of trauma and chemical injuries, uveitis, previous or concurrent contact lens use, keratitis, glaucoma, intraocular pressure of $\geq 21 \mathrm{~mm} \mathrm{Hg}$, and diabetes mellitus. A detailed history from each patient was documented on the proforma, including age, smoking status, occupation, and daily sunlight exposure. The patients were asked to estimate daily exposure to direct sunlight without any head, face and eye covering, including protective glasses. This sunlight exposure was divided into two groups (group one $<3$ hours, group two $>3$ hours) .

\section{Ophthalmic Examination}

All the patients with exclusion criteria were excluded by performing a complete necessary ophthalmological examination including; Visual Acuity, intra-ocular pressure check with Goldman Applanation Tonometer (GAT), and slit-lamp examination with the dilated ophthalmic examination were conducted for each patient.

\section{Grading of Pterygium}

The pterygium severity was graded according to the degree of visibility or obscuration of the underlying episcleral vessels on the slit lamp examination proposed by Tan et al. ${ }^{35}$ Grade 1 (Atrophic): pterygium in which episcleral vessels underlying the body of the pterygium are unobscured and distinguishable, Grade 2 (Intermediate) as a pterygium in which episcleral vessel details are indistinct or partially obscured and, Grade 3 (Fleshy) as a thick pterygium in which episcleral vessels underlying the body are obscured. The observer bias was eliminated by examining every patient independently by the two researchers (SBHZ and WAK) at two independent visits. If a consensus was not reached a third independent examiner was asked to grade the pterygium to reach a consensus.

\section{CECD Measurement}

Corneal endothelial cell density (CECD) of each patient was carried out for every eye using Non-contact specular microscopy (SP2000: Topcon Corporation, Japan). A "centre-to-centre" method was used to localize the area for measurement of cell count of the corneal endothelium.
If pterygium involved the cornea's central $4 \mathrm{~mm}$ zone where specular microscopy could not be done, a paracentral uninvolved area adjacent to pterygium was considered for measuring the cell density. Specular microscopy was done by a senior technician of the department of Ophthalmic Investigations of the ASTEH.

\section{Statistical Analysis}

Data analysis was completed using International Business Machines Statistical Package for The Social Sciences (IBM SPSS software version 20). The KolmogorovSmirnov test was employed to measure the normality of the data set (Figure 1). Quantitative variables like age, daily sun exposure, pterygium grades, and endothelial cell density (CECD) were presented as Mean \pm SD if data followed the normal distribution curve and the statistical analysis was done using paired sample $t$-test. Qualitative variables like gender and smoking were measured in frequencies and percentages, and statistical analysis was done using Chi-square test. Effect modifiers like age, gender, and smoking were controlled by stratification. A P-value of $\leq 0.05$ was taken as significant.

\section{Results}

This study's age range was $18-68$ years, with a mean age of $43.80 \pm 10.37$ years. The majority of the patients, ie, 54 $(54.0 \%)$, were $>40$ years of age. Out of these 100 patients, $62(62.0 \%)$ were male, and $38(38.0 \%)$ were females with a male to female ratio of 1.6:1 (Table 1).

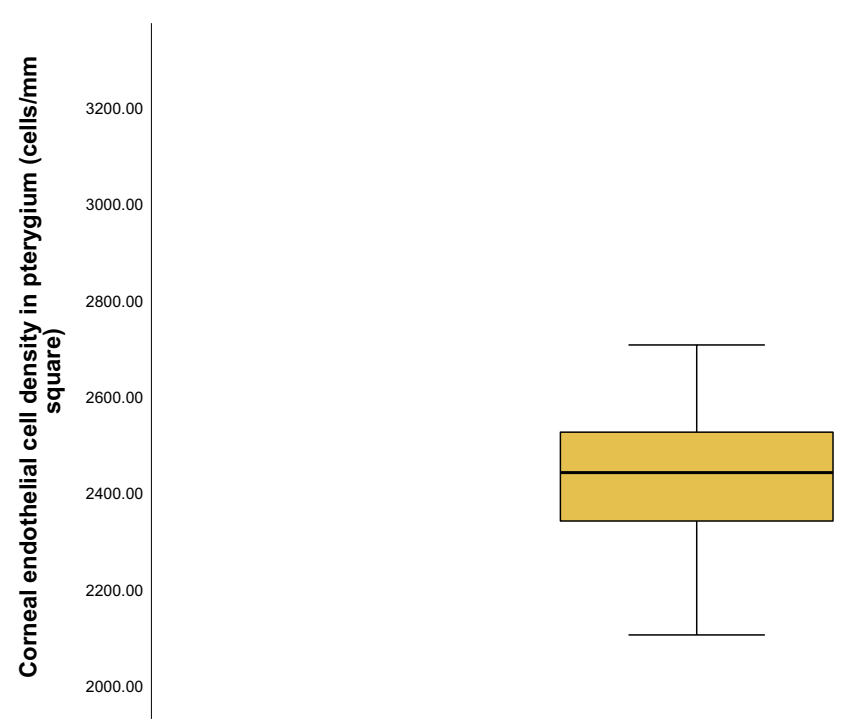

Figure I Box and Whisker plot for the corneal endothelial cell density (CECD) among diseased eyes. Note the median CECD in the centre of the box signifying the normal distribution of the sample data in the study population. 
Table I Basic Demographic Details of 100 Patients with Unilateral Pterygium

\begin{tabular}{|l|l|l|}
\hline Variables & Frequency & Percentage \\
\hline Gender & 100 & 100 \\
Male & 62 & 62.0 \\
Female & 38 & 38.0 \\
\hline Age & 100 & 100 \\
I8-40 & 46 & 46.0 \\
Greater than 40 years & 54 & 54.0 \\
\hline Daily exposure to Sun & 100 & 100 \\
Less than 3 hours & 51 & 51.0 \\
Greater than 3hours & 49 & 49.0 \\
\hline Profession & 100 & 100 \\
Farmer & 27 & 27.0 \\
Construction worker/labourer & 31 & 31.0 \\
Driver & 9 & 9.0 \\
Shopkeeper & 5 & 5.0 \\
Office worker & 7 & 7.0 \\
Homemaker & 21 & 21.0 \\
\hline Pterygium Severity & 100 & 100 \\
GRADE I(Atrophic) & 56 & 56.0 \\
GRADE 2 (Intermediate) & 26 & 26.0 \\
GRADE 3 (Fleshy) & 18 & 18.0 \\
\hline Smoking & 100 & 100 \\
Yes & 32 & 32.0 \\
No & 67 & 67.0 \\
\hline
\end{tabular}

The study population comprises six occupations with the construction workers/labourers being the most common $(n=31)$ followed by farmers $(n=27)$. The other four occupations were drivers, shopkeepers, office workers and homemakers (Table 1). The type of occupation was not significantly associated with CECD loss and pterygium grading $(\mathrm{p}=0.788)$. The daily sunlight exposure was subdivided into two groups (group 1: less than 3 hours, group 2: more than 3 hours of direct sunlight exposure). There was no significant association between daily sunlight exposure and CECD loss in pterygium group. $(\mathrm{p}=$ 0.065) (Table 2).

Mean corneal endothelial cell density (CECD) in patients with unilateral pterygium by using a non-contact specular microscope was $2411.61 \pm 143.64 \mathrm{cells} / \mathrm{mm}^{2}$ compared to healthy eyes $\left(2751.41 \pm 123.674 \mathrm{cells} / \mathrm{mm}^{2}\right)(\mathrm{P}-$ value $<0.01$ ) (Table 3).

The most common type of pterygium based on morphology was grade 1(atrophic type)(n=) followed by grade 2 and grade 3 (Table 1). The CECD loss was more in
Table 2 Stratification of CECD with Respect to Various Confounding Variables

\begin{tabular}{|c|c|c|c|}
\hline & \multicolumn{2}{|c|}{$\begin{array}{l}\text { Corneal Endothelial Cell } \\
\text { Density (CECD) in } \\
\text { Pterygium Group }\end{array}$} & \multirow[t]{2}{*}{ P-value } \\
\hline & $\begin{array}{l}\text { Mean } \\
(\text { Cells/mm²) }\end{array}$ & SD & \\
\hline \multicolumn{4}{|l|}{ Age groups (years) ${ }^{a}$} \\
\hline $18-40$ & 2401.17 & 137.08 & 0.078 \\
\hline$>40$ & 2419.70 & 136.98 & \\
\hline \multicolumn{4}{|l|}{ Gender } \\
\hline Male & 2408.77 & 131.98 & 0.563 \\
\hline Female & 2415.10 & 134.68 & \\
\hline \multicolumn{4}{|l|}{ Smoking } \\
\hline Yes & 2420.06 & 131.23 & 0.249 \\
\hline No & 2407.0 & 129.05 & \\
\hline \multicolumn{4}{|l|}{$\begin{array}{l}\text { Daily sunlight } \\
\text { exposure }\end{array}$} \\
\hline Less than 03 hours & 2406. & 132.23 & 0.650 \\
\hline Greater than 03 hours & 2414 & 133.76 & \\
\hline
\end{tabular}

Notes: Table showing association between corneal endothelial cell density with various variables. The corneal endothelial cell density $\left(\right.$ cells $\left./ \mathrm{mm}^{2}\right)$ is represented as Mean and Standard Deviation (Mean \pm SD). The table shows that age, gender smoking and daily sunlight exposure were not significantly associated with the corneal endothelial cell density loss. Stratified with respect to age to eliminate

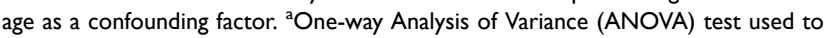
calculate $\mathrm{P}$-value $(\mathrm{P}<0.05$ was considered as significant).

fleshy (grade 3 ) pterygium (2261 cells $/ \mathrm{mm}^{2}$ ) compared to grade two and grade one pterygium $\left(2413 \mathrm{cells} / \mathrm{mm}^{2}\right.$ and 2459 cells $/ \mathrm{mm}^{2}$ respectively) (Figure 2 ).

\section{Discussion}

Pterygium is a disease of the eye's surface, which causes abnormal and exuberant proliferation of conjunctival stroma of the bulbar area and involves the cornea's anterior layers. ${ }^{8}$ Previously published data on pterygium's pathophysiology establishes an electromagnetic spectrum with ultraviolet rays (UV-A 320-400 nanometer wavelength and UV-B 280-320 nanometers wavelength) to be one of the primes factors to initiate the formation of pterygium. ${ }^{9,20}$ Population in the equatorial region with prolonged exposure to direct sunlight is most affected. ${ }^{10,11}$ It may progress to advanced eye changes like persistent lacrimation, decreased vision secondarily to astigmatic effects, and extreme cases with markedly scarred anterior corneal layers with Bowman's layer disruption. ${ }^{12-15}$ Various studies on animal and human subjects have delineated changes at the molecular level such as interleukins, 


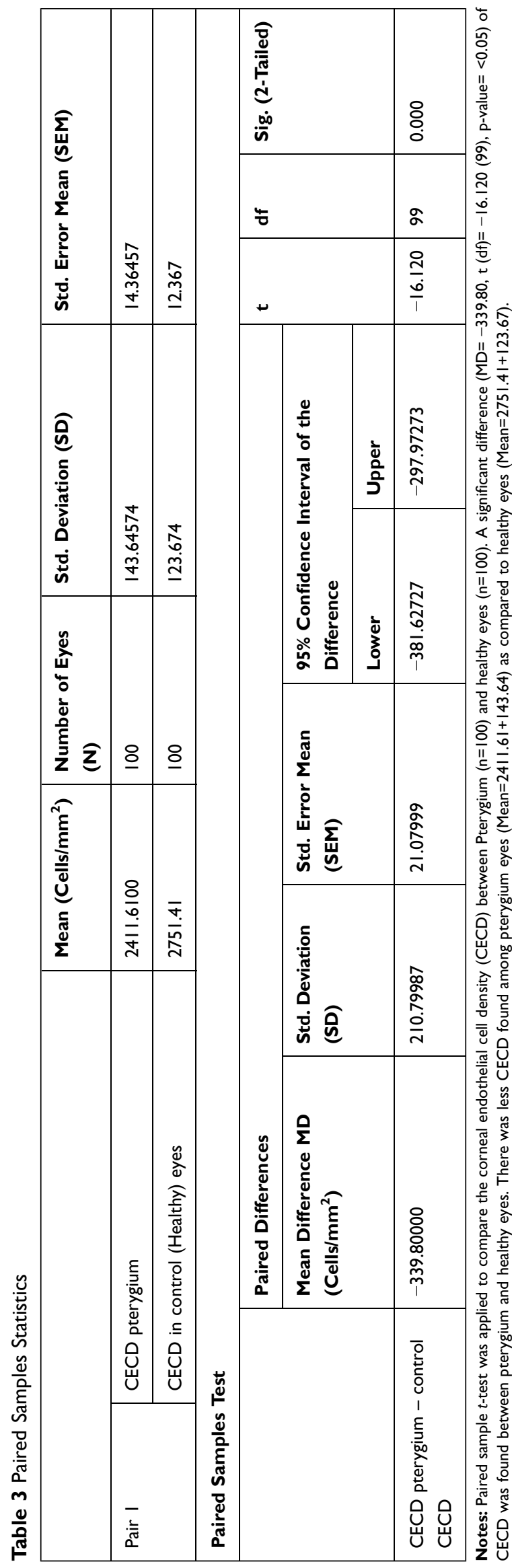

cytokines and potentiators of active chronic inflammation to affect corneal endothelium and causing a decrease in endothelial cells. ${ }^{16,17,21-24}$

We have conducted this study to determine mean corneal endothelial cells in patients with unilateral pterygium using a non-contact specular microscope and comparing the statistical difference in mean endothelial cell count between the affected and diseased eyes. This study reported a mean endothelial cell density of $2411.61 \pm 143.64$ vs $2751.41 \pm$ 123.674 cells $/ \mathrm{mm}^{2}$ in diseased and normal eyes, respectively (P-value $=0.0001)$. A study by Sousa et al conducted on sixty-one patients revealed a mean endothelial cell density of $2451.83 \pm 284.96$ cells $/ \mathrm{mm}^{2}$ vs $2549.95 \pm 268.94$ cells $/ \mathrm{mm}^{2}$ in diseased and normal eyes, respectively (Pvalue 0.04$){ }^{6}$ Another study conducted by Hsu et al depicted a statistically significant difference in endothelial cell count between $+9.6 \%$ to $-37.7 \%$, and $-9.75 \%$ Median. $^{7}$ Mootha et al studied pterygium's effects in a case series eleven eyes of seven patients with alteration in corneal layer architecture. ${ }^{18}$ They reported that although a not statistically significant yet discernable decrease in cell count was associated with increased variability of the endothelial cells' size (polymegathism) and their shape (pleomorphism) was observed with an eventual cell count of 367 cells/millimetre square less compared to eyes without pterygium. A recent study done in the Chinese population showed that there was a significant association between CECD loss and pterygium when measured retrospectively, but when measured prospectively, there was no significant association between the two variables. ${ }^{34}$ The study attributed this contradictory finding to the variability in the ECD measurement. With that knowledge, we employed a single senior-most technician to perform the corneal endothelial cell measurement using the specular microscope. Three readings per eye were performed, and an average of three readings was then noted to decrease the variability in the ECD measurement.

Specular microscopy is the most efficient method to take in-vivo photographs of corneal endothelial cells and rapidly measure the cell count without instilling anaesthetic medication into the eye. ${ }^{19}$ We used (SP2000: Topcon Corporation, Japan) to measure the total endothelial cell density. An original article by Hashemian et al on an Iranian sample size of 525 eyes depicted that mean cell count in their population was $1961 \pm 457$ cells per square millimetre measured by the same non-contact specular microscope as our study. ${ }^{25}$ A similar study on India's more than five hundred population elucidated a higher count of $2525 \pm 337$ endothelial cells $/ \mathrm{mm}^{2}{ }^{26}$ A study 


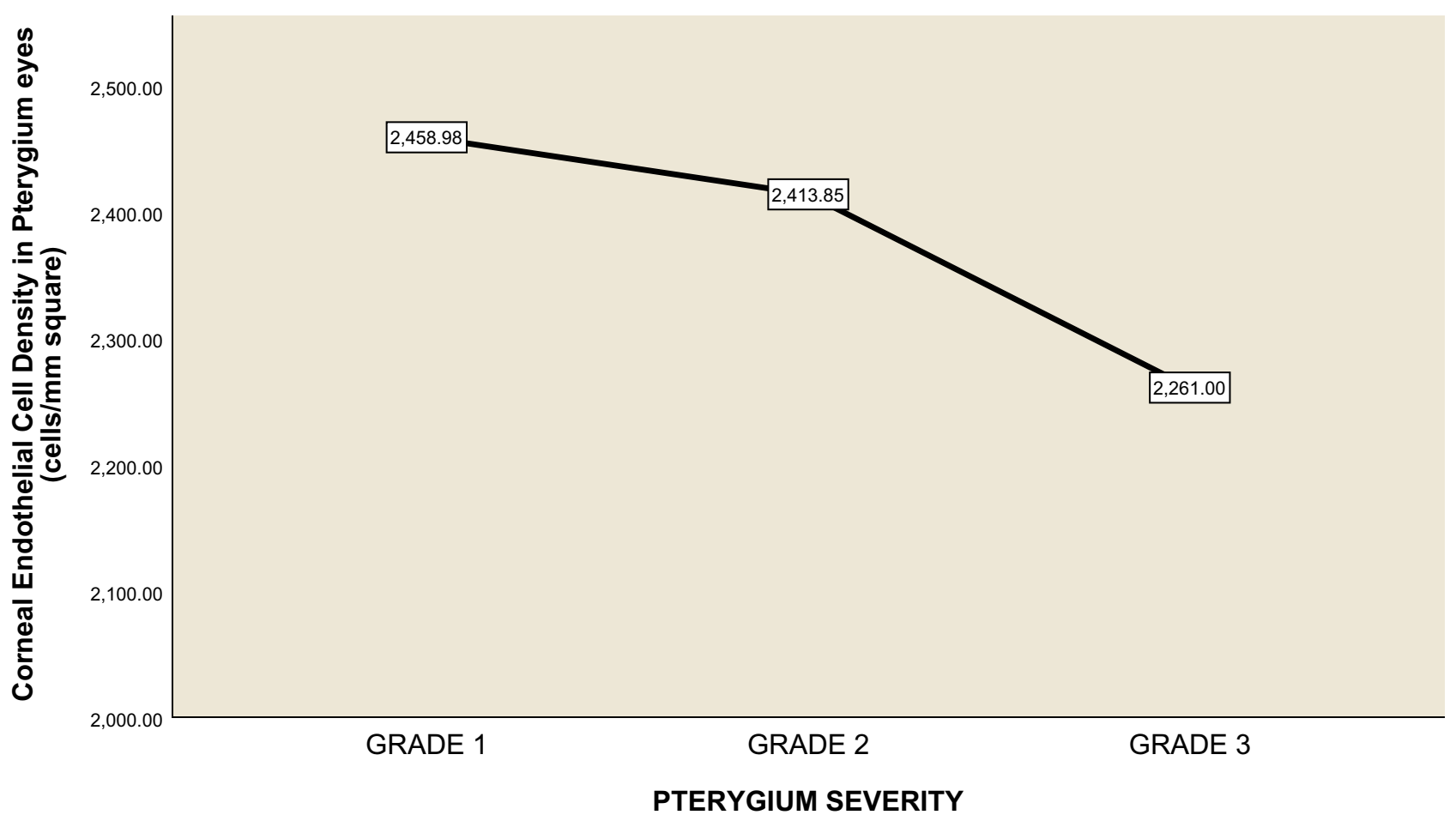

Figure 2 Relationship between mean corneal endothelial cell density (CECD) and severity of pterygium (graded according to morphology). Note that the mean CECD decreases with the progression in the grade of pterygium.

involving the Chinese population of 700 showed an even higher cell count of $2932 \pm 363 \mathrm{cell} / \mathrm{mm}^{2}{ }^{27}$ Another study on healthy eyes in the Turkish study population showed a mean CECD of $2671 \pm 356 \mathrm{cell} / \mathrm{mm}^{2} .{ }^{28}$ Our study found out comparable results of 2751.41 cells/square millimetre with an SD of 123.674 cells $(\mathrm{P}<0.0001)$ in healthy eyes.

One of the potential confounding factors associated with decreased endothelial cell loss is ultraviolet exposure. A study done by Oblaq and Doughty, which compared differences in endothelial counts between arc welders and office workers showed no difference between both groups $(\mathrm{P}=0.868) .{ }^{29}$ The most probable reason for this non-significant difference could be protective eye shields that the welders use. Corneal collagen cross-linking (especially the accelerated protocol) uses ultraviolet rays with Riboflavin primed corneal tissue to slow keratoconus progression. Previous researches have elucidated that endothelial cell count was reduced in patients with keratoconus who had accelerated CXL utilizing 5.4 joules/centimetre square constant energy dose $(\mathrm{P}<0.001) .{ }^{30}$ We asked patients to determine their average daily sunlight exposure to find a relationship between increased sunlight and ultraviolet rays exposure. We divided the variable into two categories. Our study reported no significant relationship between CECD and daily sunlight exposure $(p>0.65)$ (Table 2).

Previous studies have repeatedly shown that an increased percentage of the corneal involvement by the pterygium head causes significant endothelial loss. These studies did not account for the pterygium morphology and their association with corneal endothelial cell loss. To classify pterygium based on morphology, we used a system proposed by Tan et al. ${ }^{35}$ Our results showed that the CECD loss was greatest in patients with the grade 3 (fleshy) pterygium (2751 cells $/ \mathrm{mm}^{2}$ ) compared to the other two grades (intermediate $=2413$ cells $/ \mathrm{mm}^{2}$ and atrophic $=2459$ cells $/ \mathrm{mm}^{2}$ ) (Figure 2). Although this difference in CECD among the three grades of pterygium was not found to be significant ( $\mathrm{p}=0.065$ ), it suggests that if the pterygium is fleshy morphologically, this is more likely associated with more progressive loss of corneal endothelial cells even if the percentage of the cornea involved is less compared to a pterygium with intermediate morphology (grade 2). This study is one of the few studies which depict the effect of morphology of pterygium on CECD. This important finding has a long-lasting effect on the management of pterygium in the future 
regarding the management of pterygium with respect to cataract surgery and corneal endothelial cell loss. Further, large cohort-based studies are required to evaluate further the relationship between pterygium morphology and the endothelial cell loss.

There are a few limitations to our study:

1. The sample size is limited to 200 eyes. Although this sample size achieved a power of $90 \%$, we still think a greater sample size will be beneficial in elucidating the effects of pterygium on the corneal endothelium.

2. The duration of sunlight exposure could not objectively be assessed and potentially be limited by recall bias.

3. This study was a single-centre study of cross-sectional nature. It will be better if the data is accumulated from people of different racial backgrounds belonging to different ethnicities to enhance the study's validity.

\section{Conclusion}

This study concluded that the mean corneal endothelial cells in patients with unilateral pterygium using a noncontact specular microscope were 2411.61 \pm 143.64 cells $/ \mathrm{mm}^{2}$. So, we recommend that corneal endothelial cell density be used in every patient with pterygium by using a non-contact specular microscope to take appropriate measures to improve patients' outcomes, especially in patients requiring cataract surgery.

\section{Acknowledgment}

The authors acknowledge the support of Dr Ume Sughra Associate Professor, School of Public Health, ASTEH and Dr. Khudijah Iffat for their guidance regarding the biostatistical work in the study. The authors also acknowledge the support of the hospital staff of the Out-Patients Department of ASTEH, who are tirelessly working to provide service to the poor population of Pakistan.

\section{Funding}

No funding was received from any organization for this work.

\section{Disclosure}

The authors declare no conflicts of interest in this work.

\section{References}

1. Pajic B, Vastardis I, Rajkovic P, Pajic-Eggspuehler B, Aebersold DM, Cvejic Z. A mathematical approach to human pterygium shape. Clin Ophthalmol. 2016;10:1343-1349. doi:10.2147/OPTH.S106611

2. Cárdenas E, Zavala J, Valenzuela J, Valdez JE. Molecular basis of pterygium development. Semin Ophthalmol. 2014;31(6). doi:10.31 09/08820538.2014.971822

3. Kim YH, Jung JC, Gum SI, et al. Inhibition of pterygium fibroblast migration and outgrowth by bevacizumab and cyclosporine A involves down-regulation of matrix metalloproteinases-3 and -13 . PLoS One. 2017;12(1):e0169675. doi:10.1371/journal.pone.0169675

4. Martins TGS, Costa ALFA, Alves MR, Chammas R, Schor P. Mitomycin C in pterygium treatment. Int $J$ Ophthalmol. 2016;9 (3):465-468. doi:10.18240/ijo.2016.03.25

5. Anguria P, Kitinya J, Ntuli S, Carmichael T. The role of heredity in pterygium development. Int $J$ Ophthalmol. 2014;7(3):563-573. doi:10.3980/j.issn.2222-3959.2014.03.31

6. Sousa HCC, Silva LNP, Tzelikis PF. Corneal endothelial cell density and pterygium. A cross-sectional study. Arq Bras Oftalmol. 2017;80 (5):317-320. doi:10.5935/0004-2749.20170077

7. Hsu MY, Lee HN, Liang CY, et al. Pterygium is related to a decrease in corneal endothelial cell density. Cornea. 2014;33(7):712-715. doi:10.1097/ICO.0000000000000149

8. Coroneo MT, Di Girolamo N, Wakefield D. The pathogenesis of pterygia. Curr Opin Ophthalmol. 1999;10(4):282-288. doi:10.1097/ 00055735-199908000-00011

9. Threlfall TJ, English DR. Sun exposure and pterygium of the eye: a dose-response curve. Am J Ophthalmol. 1999;128(3):280-287. doi:10.1016/S0002-9394(99)00161-0

10. Ang M, Li X, Wong W, et al. Prevalence of and racial differences in pterygium: a multiethnic population study in Asians. Ophthalmology. 2012;119(8):1509-1515. doi:10.1016/j.ophtha.2012.02.009

11. Zhong H, Cha X, Wei T. Prevalence of and risk factors for pterygium in rural adult Chinese populations of the Bai nationality in Dali: the Yunnan Minority Eye Study. Investig Ophthalmol Vis Sci. 2012;53 (10):6617-6621. doi:10.1167/iovs.11-8947

12. Minami K, Miyata K, Otani A, Tokunaga T, Tokuda S, Amano S. Detection of increase in corneal irregularity due to pterygium using Fourier series harmonic analyses with multiple diameters. Jpn J Ophthalmol. 2018;62(3):342-348. doi:10.1007/s10384-0180583-8

13. Han SB, Jeon HS, Kim M. Quantification of astigmatism induced by pterygium using automated image analysis. Cornea. 2016;35(3):370376. doi:10.1097/ICO.0000000000000728

14. Dushku N, John MK, Schultz GS, Reid TW. Pterygia pathogenesis: corneal invasion by matrix metalloproteinase expressing altered limbal epithelial basal cells. Arch Ophthalmol. 2001;119(5):695-706. doi:10.1001/archopht.119.5.695

15. Gasser T, Romano V, Seifarth C, Bechrakis NE, Kaye SB, Steger B. Morphometric characterization of pterygium associated with corneal stromal scarring using high-resolution anterior segment optical coherence tomography. Br J Ophthalmol. 2017;101(5):660-664. doi:10.11 36/bjophthalmol-2016-308685

16. Cardenas-Cantu E, Zavala J, Valenzuela J, Valdez-Garcia JE. Molecular basis of pterygium development. Semin Ophthalmol. 2016;31(6):567-583. doi:10.3109/08820538.2014.971822

17. Liu C, Vojnovic D, Kochevar IE, Jurkunas UV. UV-A irradiation activates Nrf2-regulated antioxidant defense and induces p53/caspase3-dependent apoptosis in corneal endothelial cells. Invest Ophthalmol Vis Sci. 2016;57(4):2319-2327. doi:10.1167/iovs.1619097

18. Mootha VV, Pingree M, Jaramillo J. Pterygia with deep corneal changes. Cornea. 2004;23(6):635-638. doi:10.1097/01.ico.0000121 701.74077 .78 
19. Doughty MJ, Muller A, Zaman ML. Assessment of the reliability of human corneal endothelial cell-density estimates using a noncontact specular microscope. Cornea. 2000;19(2):148-158. doi:10.1097/ 00003226-200003000-00006

20. Gross J, Wegener AR, Kronschlager M, Holz FG, Schonfeld CL, Meyer LM. Ultraviolet radiation exposure triggers neurokinin-1 receptor upregulation in ocular tissues in vivo. Exp Eye Res. 2018;174:70-79. doi:10.1016/j.exer.2018.04.016

21. Higa A, Sakai H, Sawaguchi S, et al. Corneal endothelial cell density and associated factors in a population-based study in Japan: the Kumejima Study. Am J Ophthalmol. 2010;149(5):794-799. doi:10. 1016/j.ajo.2009.12.029

22. Talghini S, Shenasi A. Concomitant examination of inflammation and angiogenesis in the pathogenesis of primary moderate pterygium in a well-designed case-control study. Pak J Biol Sci. 2013;16(19):10461050. doi:10.3923/pjbs.2013.1046.1050

23. Tsai YY, Chiang CC, Yeh KT, Lee H, Cheng YW. Effect of TIMP-1 and MMP in pterygium invasion. Investig Ophthalmol Vis Sci. 2010;51(7):3462-3467. doi:10.1167/iovs.09-4921

24. Reda AM, Shaaban YMM, Saad El-Din SA. Histopathological parameters in pterygia and significant clinical correlations. J Ophthalmic Vis Res. 2018;13(2):110-118. doi:10.4103/jovr.jovr_31_17

25. Hashemian MN, Moghimi S, Fard MA, Fallah MR, Mansouri MR. Corneal endothelial cell density and morphology in normal Iranian eyes. BMC Ophthalmol. 2006;6(1):9. doi:10.1186/1471-2415-6-9

26. Rao SK, Ranjan Sen PR, Fogla R, Gangadraharan S, Padmanabhan P, Badrinath SS. Corneal endothelial cell density and morphology in normal Indian eyes. Cornea. 2000;19:820-823. doi:10.1097/00003 226-200011000-00012

27. Yunliang S, Yuqiang H, Ying-Peng L, Ming-Zhi Z, Lam DS, Rao SK. Corneal endothelial cell density and morphology in healthy Chinese eyes. Cornea. 2007;26(2):130-132. doi:10.1097/ICO.0b013e31802 be63e
28. Ceyhun A, Arslan OS, Dikkaya F. Corneal endothelial cell density and morphology in healthy Turkish eyes. J Ophthalmol. 2014;85 2624. doi: $10.1155 / 2014 / 852624$

29. Oblak E, Doughty MJ. Chronic exposure to the ultraviolet radiation levels from arc welding does not result in obvious damage to the human corneal endothelium. Photochem Photobiol Sci. 2002;1:857864. doi:10.1039/b205044g

30. Mooren P, Gobin L, Bostan N, et al. Evaluation of UVA cytotoxicity for human endothelium in an ex vivo corneal cross-linking experimental setting. J Refract Surg. 2016;32:41-46. doi:10.3928/10815 97X-20151207-05

31. Coroneo M. Ultraviolet radiation and the anterior eye. Eye Contact Lens. 2011;37:214-224. doi:10.1097/ICL.0b013e318223394e

32. Kataria S, Jajoo A, Guruprasad KN. Impact of increasing ultravioletB (UV-B) radiation on photosynthetic processes. J Photochem Photobiol. 2014;137:55-66. doi:10.1016/j.jphotobiol.2014.02.004

33. Allen L, Williams J, Townsend N, et al. Socioeconomic status and non-communicable disease behavioural risk factors in low-income and lower-middle-income countries: a systematic review. Lancet Glob Health. 2017;5(3):277-289. doi:10.1016/S2214-109X(17)30 058-X

34. Hu Y, Atik A, Qi W, Yuan L. The association between primary pterygium and corneal endothelial cell density. Clin Exp Optom. 2020;103:778-781. doi:10.1111/cxo.13049

35. Tan DT, Chee SP, Dear KB, et al. Effect of pterygium morphology on pterygium recurrence in a controlled trial comparing conjunctival autografting with bare sclera excision. Arch Ophthalmol. 1997;115:1235-1240. doi:10.1001/archopht.1997.01100160405001

36. Midgley K, Ha J, Korchak M, Koppinger J, Cremers S, Martinez JA. Largest report of the effect of primary pterygium on corneal endothelial cell density. Invest Ophthalmol Vis Sci. 2016;57(12):5262.
Clinical Ophthalmology

\section{Publish your work in this journal}

Clinical Ophthalmology is an international, peer-reviewed journal covering all subspecialties within ophthalmology. Key topics include: Optometry; Visual science; Pharmacology and drug therapy in eye diseases; Basic Sciences; Primary and Secondary eye care; Patient Safety and Quality of Care Improvements. This journal is indexed on PubMed

\section{Dovepress}

Central and CAS, and is the official journal of The Society of Clinical Ophthalmology (SCO). The manuscript management system is completely online and includes a very quick and fair peer-review system, which is all easy to use. Visit http://www.dovepress.com/ testimonials.php to read real quotes from published authors. 